\author{
교잡종 돼지에서 비육기간에 따른 돈육 등심의 이화학적 특성 변화 \\ 진상근 $* * *$. 김일석 $*$ 허선진 $*$ 하경희 $* *$. 김병우*** \\ 진주산업대학교 동물소재공학과*, 진주산업대학교 동물생명산업지역협력연구센터**, \\ 경상대학교 축산과학부***
}

\title{
Effects of Feeding Period on Carcass and Objective Meat Quality in Crossbred Longissimus Muscle
}

\author{
S. K. Jin*,**, I. S. Kim*, S. J. Hur*, K. H. Hah** and B. W. Kim*** \\ Department of Animal Resources Technology, Jinju National University*, \\ Regional Animal Industry Research Center, Jinju National University**, \\ Division of Animal Science, College of Agriculture, Gyeongsang National University***
}

\begin{abstract}
Objectives of this study was to determine the comparisons of physico-chemical characteristics in crossbred pigs(Korean native breed $\times$ Landrace breed) by feeding periods. A total of 150 pigs were sampled from commercial farm, and assigned into three treatedments. Feeding peirods of T1, T2 and T3 were below 200 days, 220-220 days, over 220 days, respectively. Live weight, carcass weight and backfat thickness were significantly $(\mathrm{P}<0.05)$ increased with feeding period increased, and final grade score have significantly $(\mathrm{P}<0.05)$ lower when feeding period was increased. $\mathrm{pH}$ and water content were significantly $(\mathrm{P}<0.05)$ lower when feeding period was increased(over 220days). However, intramuscular fat have no significantly different among the treatments. $\mathrm{L}^{*}$ and $\mathrm{b}^{*}$ were significantly $(\mathrm{P}<0.05)$ lower and $\mathrm{a}^{*}$ was significantly higher $(\mathrm{P}<0.05)$ when feeding period increased. Cooking loss was higher in the order of $\mathrm{T} 1>\mathrm{T} 3>\mathrm{T} 2$. Shear force values was significantly $(\mathrm{P}<$ 0.05) decreased by feed period increase. In fatty acids, myristic acid, palmitic acid, stearic acid and saturated fatty acid(SFA) in $\mathrm{T} 2$ were significantly $(\mathrm{P}<0.05)$ lower in $\mathrm{T} 2$, whereas linolenic acid, unsaturated fatty acid(UFA), essential fatty acid(EFA), UFA/SFA and EFA/SFA were significantly higher in T2 compared with other treatment. However palmitoleic acid and arachidonic acid were no significantly different with feeding periods. As a result of this study, crossbred pigs was increased live weight and carcass weight with feeding periods, and improved meat color and tenderness with feeding periods. However, final grade score was decreased with feeding periods.
\end{abstract}

(Key words : Crossbred pigs, Physico-chemical characteristics, Pork, Growing period, Fatty acid)

\section{I 서 론}

일반적으로 백색계 교잡종 돼지의 경우 150 180 일령 정도에 출하가 이루어지고 있으며 최 근에 들어 브랜드육 생산 차원에서 좋은 육의 생산을 위하여 출하일령은 늦추면서 비육후기
에 사료의 영양수준을 낮추거나 제한급이를 통 한 출하일령을 늘리는 방향으로 많은 관심들을 갖고 있다. 그러나 재래돼지와 랜드레이스를 교잡하여 생산된 비육돈의 경우 생산효율이 낮 아 일정한 출하체중을 맞추기 위해서는 비육기 간을 연장할 수밖에 없다. 비육기간이 늘어남

Corresponding author : S. K. Jin, Department of Animal Resources Technology, Jinju National University, 660-758, Jinju, Korea. Tel : 82-55-751-3283, Fax : 82-55-751-3514, E-mail : skjin@jinju.ac.kr 
으로써 출하체중이 증가하고 출하체중 증가시 뒷다리와 어깨부위육의 비율은 감소하고 등심 과 삼겹살부위육은 증가하게 되며(Martin et al., 1980; Cisneros et al., 1996), 돈육의 육질도 변 화하게 된다. 도축시 나이와 체중의 증가는 근 육의 특성과 돈육의 관능적 품질에 영향을 미 치며(Berry et al., 1970; Martin et al., 1980), 근 간지방의 농도를 높이게 된다(Krieter et al., 1989; Candek-Potokar et al., 1996). 출하일령을 늘리기 위하여 제한급이를 할 경우 근간지방은 줄게되며(Ognjanovic et al., 1973), 연도와 다즙 성 또한 감소하게 된다(Ellis et al., 1990; Warkup et al., 1990). Sather 등(1991)은 생체중 이나 도체중에 따라 육질은 영향을 받지 않는 다고 보고하였으나 Touraille 등(1989)은 체중의 차이에 의해 근육내 콜라겐 함량에 차이를 보 인다고 보고하였다. 또한 Shuler 등(1970)과 Sutton 등(1997)은 육색과 도체중 간에는 관련 이 없다고 하였으며, 반면에 Berry 등(1970)과 Martin 등(1980)은 도체중 증가는 육색과 유의 적인 변화를 나타낸다고 하였다. Sanudo 등 (1996)과 Vergara 등(1999)은 양의 체중 증가에 따라 힘색소량이 증가하여 $\mathrm{L}^{*}$ 값은 줄고 $\mathrm{a}^{*}$ 값 은 높아진다고 하였다. Choi 등(2000)은 일반 백색계 삼원교잡종 $(\mathrm{LY} \times \mathrm{D})$ 의 출하일령에 따라 $\mathrm{pH}$ 는 차이를 보이지 않으며, 출하일령이 길수 록 보수력은 높고 육즙 손실이 적으며, $\mathrm{L}^{*}$ 값은 낮고, $\mathrm{a}^{*}$ 값과 $\mathrm{b}^{*}$ 값은 출하일령 간에 차이를 보이지 않았다고 하였다. Rhim 등(1995)은 삼원 교잡종 $(\mathrm{HY} \times \mathrm{D})$ 의 연령이 증가할수록 육의 수 분 함량은 220 일령까지 줄고 그 이후 다시 증 가하였고, 조지방 함량은 수분과는 반대 경향 을 나타내었으며, 연도는 증가한 이후 다시 감 소한다고 하였다. Candek-Potokar 등(1998)의 체 중이 증가할수록 연도와 씹힘성은 줄고 입으로 느끼는 전체적인 저작감 점수 역시 낮아진다고 보고하였는데, Vergara 등(1999)은 체중 증가에 따른 경도에는 차이를 보이지 않았다고 하였 다. Shuler 등(1970)도 출하체중이 증가할수록 수분 함량은 줄고 조지방 함량은 늘어난다고
하였으며, Beattie 등(1999)은 체중 증가에 따라 육즙 손실은 증가한다고 하였다. 또한 Sanudo 등(1996)은 양의 체중 증가에 따라 $\mathrm{pH}$ 는 증가 한다고 하였다. 본 연구에서는 일반 백색계 삼 원교잡에 비하여 성장속도가 늦은 재래돼지와 랜드레이스 교잡에 따라 생산된 비육돈의 비육 기간에 따른 도체특성과 육의 이화학적 특성 비교를 통해 적절한 비육기간을 제시하고 우리 고유의 재래돼지의 활용에 대한 기초자료를 제 시하고자 실시하였다.

\section{ㅍ 재료 및 방법}

\section{1. 시험 동물 및 시험설계}

본 시험은 경남 거창육종에서 사육된 Landrace 암컷과 경북 포항 $\mathrm{S}$ 농장의 재래돼지 수컷을 교 배하여 생산된 F1 150두를 공시하였다. 사료급 여는 일령 단계별로 자돈, 육성돈, 비육후기사 료로 구분하여 일반 상업용 배합사료를 급여하 였다. 비육기간은 3처리구로 나누었으며, T1(200 일 미만), T2(200 220일), T3(220일 초과)로 하 였다.

\section{2. 시험방법}

(1) 공시재료

공시재료는 도축 후 1 일 냉장실 $\left(2 \pm 2^{\circ} \mathrm{C}\right)$ 에서 냉각한 후 좌반도체의 등심(배최장근)을 분할정 형하여 랩포장한 후 $0 \pm 1^{\circ} \mathrm{C}$ 온도에서 1 일 경과 후 육질분석을 위한 공시재료로 이용하였다.

\section{(2) 조사항목 및 방법}

\section{1) 도체특성}

도축장으로 이송된 공시돼지는 생체중을 측 정하고 도축한 후 도체를 수세하여 온도체 상 태에서 도체중량을 측정하여 생체중 대비 지육 율(도체율)을 계산하였다. 등지방 두께는 $5^{\circ} \mathrm{C}$ 이 하로 예냉된 도체의 좌반도체(左牛屠體)의 최후 흉추와 제 1 요추 사이에서 척추골과 직각되게 
지방의 두께를 측정하였으며, 등급판정은 축산 물등급판정소의 판정기준으로 육류등급사에 의 해 판정하였다.

$$
\text { 지육율(도체율) } \%=\frac{\text { 도체중 }}{\text { 생체중 }} \times 100
$$

\section{2) 일반성분}

가. 수분

수분은 $102 \pm 2^{\circ} \mathrm{C}$ 의 건조기에서 24 시간 건조 후 중량을 측정하여 건조전 시료중량에 대한 백분율 $(\%)$ 로 나타내었다.

수분(\%) $=$

건조전 시료 무게 $(\mathrm{g})$ - 건조후 시료 무게 $(\mathrm{g})$

$$
\text { 시료 무게 }(g)
$$

\section{나. 조지방}

조지방은 Soxhlet 추출법으로 측정하였으며, 시료를 Soxhlet 추출기에 넣고 ether로 추출 후 ether를 제거한 후에 건조하여 다음과 같이 계 산하였다.

조진방 $(\%)=$

$\frac{\text { 추출전 시료 무게 }(g) \text { - 추출후 시료 무게 }(g)}{\text { 시료 무게 }(g)} \times 100$

\section{3) $\mathbf{p H}$}

근막, 지방 등을 제거한 후 세절한 시료 $3 \mathrm{~g}$ 을 $\mathrm{pH}$ 6.8의 증류수 $27 \mathrm{ml}$ 와 함께 homogenizer (MSE, U.S.A.)로 $14,000 \mathrm{rpm}$ 에서 10 초간 균질하 여 $\mathrm{pH}$-meter(Metrohm 632, Swiss)로 측정하였다.

\section{4) 육색 및 지방색}

육색은 등심근 단면적의 전부위를 균일하게 측정하였으며, 지방색은 등심에 붙어있는 등지 방 부위를 측정하였는데, chroma meter(Model CR-210, Minolta Co. LTD. Japan)를 사용하여 동일한 시료를 9회 반복 측정하였다. 이때 표 준색판은 $\mathrm{L}^{*}=89.2, \mathrm{a}^{*}=0.921, \mathrm{~b}^{*}=0.783$ 으로 하 였다.

\section{5) 가열감량}

가열감량은 시료를 $2 \mathrm{~cm}$ 두께로 일정하게 절 단하여 무게를 측정한 다음(A), zipper bag에 넣 고 water bath에서 심부온도가 $70^{\circ} \mathrm{C}$ 에 도달할 때까지 가열한 후 식힌 다음 시료의 무게를 측 정하여(B) 산출하였다. 이때 가열감량을 산출하 는 공식은 아래와 같다.

$$
\text { 가열감량 }(\%)=\frac{(A-B)}{(A)} \times 100
$$

6) 전단가 및 조직감

전단가와 조직감은 등심육을 가로세로 $3 \mathrm{~cm}$ 되게 절단하여 근육방향에 직각이 되게 측정하 였으며, 신선육은 shearing cutting test로 shear force 값을 나타내었고, 가열육은 가열감량과 동일한 방법으로 가열한 후 mastication test로 시 험하였고, Rheometer(Sun Scientific Co., Compac100 , Japan) 측정조건은 다음 Table 1 과 같다. 신선육은 전단력 측정(shear force), 가열육은 파쇄 성(brittleness), 경도(hardness), 응집성(cohesiveness), 탄력성(elasticity), 점착성(gumminess), 씹힘성 (chewiness)을 조사하였다.

Table 1. Conditions of Rheometer for texture analysis

\begin{tabular}{lcc}
\hline Items & Fresh meat & Cooked meat \\
\hline \hline Table speed & $120 \mathrm{~mm} / \mathrm{min}$ & $120 \mathrm{~mm} / \mathrm{min}$ \\
\hline Sample speed & $60 \mathrm{~ms}$ & $50 \mathrm{~ms}$ \\
\hline Load cell & $10 \mathrm{~kg}$ & $10 \mathrm{~kg}$ \\
\hline Adapter area & $30 \mathrm{~mm}^{2}$ & $5 \mathrm{~mm}^{2}$ \\
\hline Sample area & $10 \times 20 \mathrm{~mm}^{2}$ & $25 \times 25 \mathrm{~mm}^{2}$ \\
\hline
\end{tabular}

7) 지방산

등심육을 Folch 등(1957)의 방법을 이용하여 조지방을 추출하고, 추출된 조지방 시료에 chloroform $1 \mathrm{ml}$ 을 넣어 녹인 다음, 이중 $100 \mu \mathrm{l}$ 를 취하여 $20 \mathrm{ml}$ tube에 넣는다. 이때 $1 \mathrm{ml}$ 의 methylation(methanolic-HCl-3N) 시약을 넣고 waterbath에서 $60^{\circ} \mathrm{C}$ 로 40 분간 반응시킨다. 반응이 
끝난 후 방냉시키고, hexane $3 \mathrm{ml}$ 과 증류수 8 $\mathrm{ml}$ 을 넣고 강하게 섞어준 다음 시료를 24시간 방치하여 층분리시키고 층분리가 끝난 상층 1 $\mathrm{ml}$ 을 Gas chromatography(GC)로 분석하였다. 지 방산 분석시 GC의 조건은 Table 2와 같다.

Table 2. Conditions of GC for fatty acid analysis

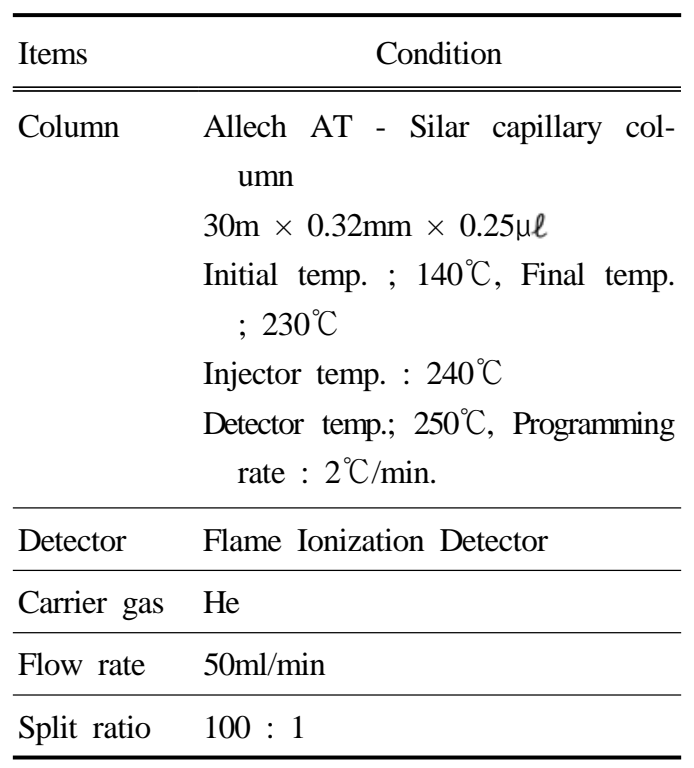

\section{3. 통계분석}

모든 시험에서 얻어진 성적은 GLM procedure(SAS)를 이용 ANOVA를 실시하여 유의성 이 있는 것만 처리수가 적은 것은 T-test에 의 해서 유의차를 검정하였고, 처리수가 많은 것
은 Tukeys test에 의해서 유의차 검정을 실시하 였다.

\section{III 결과 및 고찰}

1. 생체중, 도체중, 지육율, 등지방두께 및 등급

비육기간에 따른 생체중, 도체중, 지육율, 등 지방두께 및 등급은 Table 3과 같다. 비육기간 이 증가할수록 생체중, 도체중 및 등지방두께 는 유의적으로 $(\mathrm{P}<0.05)$ 증가하였고 최종 도체 등급은 유의적으로 $(\mathrm{P}<0.05)$ 낮게 나타났다. 그 러나 지육율은 비육기간 간에 차이를 보이지 않았다. Fortin(1980)은 도체중이 클수록 거래정 육량이 많았다고 보고하였는데, 본 연구에서 재래돼지와 Landrace 교배종 역시 비육기간의 증가에 의해 생체중과 도체중은 증가하는 경향 을 나타내었다. Friesen 등(1994)은 출하체중 $104 \mathrm{~kg}$ 인 돼지의 도체율이 $71.91 \sim 74.11 \%$ 이었 다고 보고하였으며, Sather 등(1991)은 돼지 품 종에 따라 도체특성은 유의적인 차이가 없었 고, 적육, 지방, 뼈 비율도 성별에 관계없이 유 사하였으며, 생체중 $90 \mathrm{~kg}$ 의 돼지에서 온도체중 은 암퇘지가 $77.8 \mathrm{~kg}$ 수퇘지는 $75 \mathrm{~kg}$ 이었다고 보 고하였다. 본 연구에서 재래돼지와 Landrace 교 배종 또한 생체중이 $100 \mathrm{~kg}$ 일 때 도체율이 $74.85 \mathrm{~kg}$ 을 나타내어 외래 도입종 돼지와 유사 한 도체중을 나타내는 것으로 나타났다. 또한

Table 3. Changes of carcass characteristics with feeding periods in crossbred pigs

\begin{tabular}{cccccc}
\hline Treatments $^{1)}$ & $\begin{array}{c}\text { Live weight. } \\
(\mathrm{kg})\end{array}$ & $\begin{array}{c}\text { Carcass weight. } \\
(\mathrm{kg})\end{array}$ & $\begin{array}{c}\text { Dressing percent } \\
(\%)\end{array}$ & $\begin{array}{c}\text { Backfat thickness } \\
(\mathrm{mm})\end{array}$ & Final grade $^{2)}$ \\
\hline \hline $\mathrm{T} 1$ & $83.51^{\mathrm{b}} \pm 1.96$ & $62.20^{\mathrm{b}} \pm 1.55$ & $74.46 \pm 0.87$ & $18.51^{\mathrm{b}} \pm 0.88$ & $3.73^{\mathrm{a}} \pm 0.09$ \\
\hline $\mathrm{T} 2$ & $85.44^{\mathrm{b}} \pm 1.60$ & $63.70^{\mathrm{b}} \pm 1.26$ & $72.31 \pm 0.71$ & $16.90^{\mathrm{b}} \pm 0.72$ & $3.74^{\mathrm{a}} \pm 0.08$ \\
\hline $\mathrm{T} 3$ & $100.00^{\mathrm{a}} \pm 2.65$ & $74.85^{\mathrm{a}} \pm 2.10$ & $74.74 \pm 1.18$ & $21.92^{\mathrm{a}} \pm 1.19$ & $3.33^{\mathrm{b}} \pm 0.13$ \\
\hline
\end{tabular}

Means \pm S.D.

${ }^{\mathrm{a}, \mathrm{b}}$ Means with different superscript in the same column significantly $\operatorname{differ}(\mathrm{P}<0.05)$.

1) T1(below 200days), T2(200-220days), T3(over 220days). ${ }^{2)}$ (A grade) $\sim 1$ (E grade). 
비육기간의 증가에 의해 생체중과 도체중 및 등지방 두께가 두꺼워지며 등급은 낮아지는 것 으로 나타났다.

\section{2. 일반성분, $\mathrm{pH}$, 전단가 및 가열감량}

비육기간에 따른 돈육의 수분 및 조지방 함량, $\mathrm{pH}$, 전단가 및 가열감량은 Table 4와 같다. 비육기간이 증가할수록 수분 함량은 유 의적으로 $(\mathrm{P}<0.05)$ 낮았으며, $\mathrm{pH}$ 는 유의적으 로 $(\mathrm{P}<0.05)$ 높게 나타났다. 전단가는 $\mathrm{T} 3$ 구에 서 유의적으로 $(\mathrm{P}<0.05)$ 낮아 비육기간 220 일 이상 증가시 전단력가가 낮은 것으로 나타났 다. 조지방 함량은 비육기간 간에 차이를 보이 지 않았으나, 가열감량은 비육기간이 가장 짧 은 $\mathrm{T} 1$ 구가 가장 많았으며 $(\mathrm{P}<0.05)$, 비육기간 이 중간인 $\mathrm{T} 2$ 구가 유의적으로 $(\mathrm{P}<0.05)$ 가장 적은 가열감량을 나타내었다. Choi 등(2000)은 일반 백색계 삼원교잡종 $(\mathrm{L} \times \mathrm{Y} \times \mathrm{D})$ 의 출하일 령에 따라 $\mathrm{pH}$ 는 차이를 보이지 않는다고 하여 본 연구 결과와는 차이를 보였으나 이는 교배 체계의 차이에 따른 출하일령의 차이에 기인 되는 것으로 판단된다. 그러나 출하일령이 길 수록 보수력은 높고 육즙 손실은 적다고 하여 본 연구 결과와 유사한 결과였다. Rhim 등 (1995)은 삼원교잡종 $(\mathrm{HY} \times \mathrm{D})$ 의 연령이 증가할 수록 육의 수분 함량은 220일령까지 줄고 그 이후 다시 증가하는 경향이었으며, 조지방 함
량은 반대로 증가한 이후 감소한다고 하였다. Shuler 등(1970)도 출하체중이 증가할수록 수 분 함량은 줄고 조지방 함량은 늘어난다고 하 였다. Martin 등(1980)과 Monin 등(1999)은 등 심의 지방 함량은 $137 \mathrm{~kg}$ 출하체중까지는 체 중의 영향을 받지 않는다고 하여 본 연구 결 과와 일치하였다. 비육기간이 짧을수록 체중이 가벼운 것을 감안할 때 체중 증가에 따라 육 즙 손실은 증가한다고 한 보고(Beattie et al., 1999)와는 차이를 보였다. 한편 Sanudo 등 (1996)은 양에 있어 체중 증가는 $\mathrm{pH}$ 를 증가시 킨다고 보고하여 본 연구 결과와 일치하는 결 과였으나, Cisneros 등(1996)은 돼지의 도살체 중이 증가함에 따라 최종 $\mathrm{pH}$ 가 낮아져 $\mathrm{PSE}$ 육 발생 가능성이 높다고 한 보고와는 차이를 보 였다. 본 연구결과 재래종과 랜드레이스 교잡 종 돼지는 비육기간의 증가에 의해 $\mathrm{pH}$ 가 증가 되었고, 이러한 $\mathrm{pH}$ 의 증가는 연도의 향상과 가열감량의 감소와 일부 관련이 있을것으로 사료된다. 따라서 재래돼지와 랜드레이스 교잡 종은 220일 이상의 비육을 통해 지방의 축적 없이 식육의 품질을 다소 향상시킬 수 있을 것으로 사료된다.

\section{3. 육색 및 지방색}

비육기간에 따른 돈육의 육색 및 지방색은 Table 5과 같다. 육색의 명도를 나타내는 $\mathrm{L}^{*}$

Table 4. Changes of water, crude fat, $\mathrm{pH}$, shear force and cooking loss with feeding periods in crossbred pigs

\begin{tabular}{cccccc}
\hline Treatments $^{1)}$ & Water (\%) & Intramuscular fat (\%) & $\mathrm{pH}$ & Shear force $\left(\mathrm{g} / \mathrm{cm}^{2}\right)$ & Cooking loss (\%) \\
\hline \hline $\mathrm{T} 1$ & $74.87^{\mathrm{a}} \pm 0.39$ & $3.42 \pm 1.51$ & $5.34^{\mathrm{b}} \pm 0.05$ & $2,908^{\mathrm{a}} \pm 2,338$ & $41.97^{\mathrm{a}} \pm 2.57$ \\
\hline $\mathrm{T} 2$ & $74.06^{\mathrm{b}} \pm 0.37$ & $3.53 \pm 1.41$ & $5.32^{\mathrm{b}} \pm 0.05$ & $2,999^{\mathrm{a}} \pm 219$ & $30.86^{\mathrm{c}} \pm 2.42$ \\
\hline $\mathrm{T} 3$ & $73.80^{\mathrm{b}} \pm 0.43$ & $3.41 \pm 1.67$ & $5.48^{\mathrm{a}} \pm 0.06$ & $2,421^{\mathrm{b}} \pm 2259$ & $35.30^{\mathrm{b}} \pm 2.85$
\end{tabular}

Means \pm S.D.

a,b,c Means with different superscript in the same column significantly $\operatorname{differ}(\mathrm{P}<0.05)$.

1) T1(below 200days), T2(200 220days), T3(over 220days). 
Table 5. Changes of meat and fat color with feeding periods in crossbred pigs

\begin{tabular}{|c|c|c|c|c|c|c|}
\hline \multirow{2}{*}{ Treatments $^{1)}$} & \multicolumn{3}{|c|}{ Meat color } & \multicolumn{3}{|c|}{ Fat color } \\
\hline & $\mathrm{L}^{*}$ & $\mathrm{a}^{*}$ & $b^{*}$ & $\mathrm{~L}^{*}$ & $a^{*}$ & $\mathrm{~b}^{*}$ \\
\hline $\mathrm{T} 1$ & $51.67^{\mathrm{a}} \pm 3.09$ & $5.07^{\mathrm{b}} \pm 0.94$ & $7.54^{\mathrm{a}} \pm 1.47$ & $72.80^{\mathrm{a}} \pm 0.70$ & $1.70^{\mathrm{b}} \pm 0.57$ & $4.22^{\mathrm{a}} \pm 0.56$ \\
\hline $\mathrm{T} 2$ & $49.48^{\mathrm{a}} \pm 2.90$ & $7.03^{\mathrm{a}} \pm 0.89$ & $7.51^{\mathrm{a}} \pm 1.38$ & $71.21^{b} \pm 0.65$ & $2.18^{\mathrm{ab}} \pm 0.53$ & $4.46^{\mathrm{a}} \pm 0.53$ \\
\hline T3 & $44.43^{\mathrm{b}} \pm 3.43$ & $7.87^{\mathrm{a}} \pm 1.05$ & $3.03^{\mathrm{b}} \pm 1.63$ & $71.22^{\mathrm{b}} \pm 0.77$ & $3.08^{\mathrm{a}} \pm 0.63$ & $1.99^{b} \pm 0.62$ \\
\hline
\end{tabular}

값과 황색도를 나타내는 $\mathrm{b}^{*}$ 값은 비육기간이 가장 긴 $\mathrm{T} 3$ 구가 $\mathrm{T} 1$ 과 $\mathrm{T} 2$ 구에 비하여 유의적 으로 $(\mathrm{P}<0.05)$ 낮았으며, 적색도를 나타내는 $\mathrm{a}^{*}$ 값은 비육기간이 가장 긴 $\mathrm{T} 2$ 와 $\mathrm{T} 3$ 구가 $\mathrm{T} 1$ 구에 비하여 유의적으로 $(\mathrm{P}<0.05)$ 높게 나타났 다. 본 연구결과 재래돼지와 랜드레이스 교잡 종 돼지는 비육기간이 증가할수록 명도는 줄 고 적색도는 증가하는 것으로 나타났다. Choi 등(2000)은 일반 백색계 삼원교잡종 $(\mathrm{LY} \times \mathrm{D})$ 의 출하일령이 낮을수록 $\mathrm{L}^{*}$ 값은 높다고 하여 본 연구 결과와 일치하는 결과였으나 $\mathrm{a}^{*}$ 값과 $\mathrm{b}^{*}$ 값은 출하일령 간에 차이를 보이지 않았다고 하여 본 연구 결과와는 차이를 보였는데 이는 교배체계의 차이에 따른 출하일령의 차이가 크기 때문인 것으로 판단된다. 지방색은 $\mathrm{L}^{*}$ 값은 비육기간이 가장 짧은 $\mathrm{T} 1$ 구가 $\mathrm{T} 2$ 와 $\mathrm{T} 3$ 구에 비하여 유의적으로 $(\mathrm{P}<0.05)$ 높았으며, $\mathrm{a}^{*}$ 값은 $\mathrm{T} 3, \mathrm{~T} 2, \mathrm{~T} 1$ 순으로 유의적으로 $(\mathrm{P}<0.05)$ 낮아 비육기간이 증가할수록 적색도는 높게 나타났다. $\mathrm{b}^{*}$ 값은 $\mathrm{T} 3$ 구가 $\mathrm{T} 1$ 과 $\mathrm{T} 2$ 구에 비하 여 유의적으로 $(\mathrm{P}<0.05)$ 낮아 비육기간이 증가 할수록 황색도가 낮은 결과를 보였다. 일반적 으로 비육기간이 길수록 도체중이 무거운 것 을 감안할 때 Berry 등(1970)과 Martin 등 (1980)은 도체중 증가는 육색과 유의적인 변 화를 나타낸다고 한 보고와 Sanudo 등(1996) 과 Vergara 등(1999)은 양의 체중증가에 따라
힘색소량이 증가하고 $\mathrm{L}^{*}$ 값은 줄고 $\mathrm{a}^{*}$ 값은 높아진다고 한 보고와 본 연구 결과와는 일치 하는 결과였다. 그러나 Cisneros 등(1996)은 도 살체중이 증가할수록 육색은 옅어진다고 하여 차이를 보였다. 본 연구결과를 종합적으로 볼 때 재래종과 랜드레이스 교잡종 돼지의 육색 및 지방색은 공히 비육기간이 길어질수록 $\mathrm{L}^{*}$ 값과 $\mathrm{b}^{*}$ 값은 낮아지고, $\mathrm{a}^{*}$ 값은 높아지는 것 으로 나타났으며, 이는 비육기간의 증가에 따 른 육색소의 증가에 의한 것으로 사료되어진 다. 따라서 비육기간의 증가에 의해 육색은 향상되는 것으로 나타났다.

\section{4. 가열육의 조직감}

비육기간에 따른 가열 돈육의 조직감은 Table 6과 같다. 경도는 비육기간이 가장 긴 $\mathrm{T} 3$ 구가 $\mathrm{T} 1$ 과 $\mathrm{T} 2$ 구에 비하여 유의적으로 $(\mathrm{P}<$ $0.05)$ 높았으며, 부착성과 탄력성은 비육기간 이 길어질수록 유의적으로 $(\mathrm{P}<0.05)$ 낮아지는 결과였다. 점착성과 파쇄성은 비육기간이 중 간인 $\mathrm{T} 2$ 구가 $\mathrm{T} 1$ 과 $\mathrm{T} 3$ 구에 비하여 유의적으 로 $(\mathrm{P}<0.05)$ 낮은 결과를 보였다. 그러나 응집 성은 비육기간에 따른 차이를 보이지 않았다. 본 연구결과를 종합적으로 볼 때 재래종과 랜드레이스 교배종 돼지는 비육기간이 길어 질수록 경도, 점착성은 높아지고, 부착성, 탄 
Table 6. Changes of texture with feeding periods in crossbred pigs

\begin{tabular}{ccccccc}
\hline Treatments $^{1)}$ & $\begin{array}{c}\text { Hardness } \\
\left(\mathrm{g} / \mathrm{cm}^{2}\right)\end{array}$ & $\begin{array}{c}\text { Adhesiveness } \\
(\mathrm{g})\end{array}$ & $\begin{array}{c}\text { Cohesiveness } \\
(\%)\end{array}$ & $\begin{array}{c}\text { Springness } \\
(\%)\end{array}$ & $\begin{array}{c}\text { Gumminess } \\
(\mathrm{g})\end{array}$ & $\begin{array}{c}\text { Brittle-ness } \\
(\mathrm{g})\end{array}$ \\
\hline \hline $\mathrm{T} 1$ & $16,266^{\mathrm{b}} \pm 2,459$ & $318^{\mathrm{a}} \pm 44$ & $48.71 \pm 2.70$ & $85.59^{\mathrm{a}} \pm 4.32$ & $456^{\mathrm{b}} \pm 45.11$ & $417^{\mathrm{a}} \pm 47$ \\
\hline $\mathrm{T} 2$ & $15,564^{\mathrm{b}} \pm 2,310$ & $224^{\mathrm{b}} \pm 41$ & $44.30 \pm 2.54$ & $83.07^{\mathrm{a}} \pm 4.06$ & $364^{\mathrm{c}} \pm 42.38$ & $319^{\mathrm{b}} \pm 45$ \\
\hline & & & & & & \\
$\mathrm{T} 3$ & $39,320^{\mathrm{a}} \pm 2,728$ & $148^{\mathrm{c}} \pm 49$ & $45.10 \pm 3.00$ & $74.70^{\mathrm{b}} \pm 4.80$ & $551^{\mathrm{a}} \pm 50.05$ & $434^{\mathrm{a}} \pm 53$ \\
\hline
\end{tabular}

Means \pm S.D.

${ }^{a, b, c}$ Means with different superscript in the same column significantly $\operatorname{differ}(\mathrm{P}<0.05)$.

1) T1(below 200days), T2(200 220days), T3(over 220days).

력성 및 파쇄성은 낮았으며 응집성은 비육기 간 간에 차이를 보이지 않는 것으로 나타났 다. Rhim 등 (1995)은 삼원교잡종 $(\mathrm{HY} \times \mathrm{D})$ 의 연령이 증가할수록 220 일령까지 연도는 증가 한 이후 감소한다고 하여 본 연구 결과와는 차이를 보였다. 또한 Cisneros 등(1996)은 도 살체중이 증가할수록 경도가 감소한다고 하 여 본 연구 결과와는 차이를 보였다. 비육기 간이 증가할수록 도체중이 증가하는 것을 감 안할 때 Candek-Potokar 등(1998)의 체중이 증 가할수록 연도와 씹힘성은 줄고 입으로 느끼 는 전체적인 저작감 점수 역시 낮아진다고 한 보고와 일치하는 경향이었다. 또한 Vergara 등(1999)은 체중 증가로 경도에는 차이를 보 이지 않았다는 보고와는 차이를 보였다. 이러 한 연구 결과 차이는 품종, 성별 및 도살 전 후 처리의 차이 때문인 것으로 판단된다 $(\mathrm{Gu}$ et al., 1992; Friesen et al., 1994).

\section{5. 지방산 조성}

비육기간에 따른 돈육의 지방산 조성은 Table 7과 같다. Myristic acid와 palmitic acid 의 수준은 비육기간이 증가할수록 유의적으 로 $(\mathrm{P}<0.05)$ 감소하였으며, stearic산은 비육기 간이 가장 긴 $\mathrm{T} 3$ 구가 유의적으로 $(\mathrm{P}<0.05)$ 가 장 높은 수준을 나타내었고, 비육기간이 중간 인 $\mathrm{T} 2$ 구에서 stearic acid의 수준이 유의적으
로 $(\mathrm{P}<0.5)$ 가장 낮았다. Linoleic acid와 arachidonic acid의 수준은 비육기간이 중간인 $\mathrm{T} 2$ 구 에서 유의적으로 $(\mathrm{P}<0.05)$ 가장 낮게 나타났 다. 그러나 Palmitoleic acid와 oleic acid는 비 육기간 간에 따른 차이를 보이지 않았다. 포 화지방산의 비율은 $\mathrm{T} 2$ 가 $\mathrm{T} 1$ 과 $\mathrm{T} 3$ 에 비하여 유의적으로 낮았으며, 불포화지방산, 필수지 방산, 불포화지방산/포화지방산, 필수지방산/ 포화지방산의 비율은 $\mathrm{T} 2$ 구가 $\mathrm{T} 1$ 과 $\mathrm{T} 3$ 구에 비하여 유의적으로 높았다. 일반적으로 포화 지방산의 증가는 지방경도의 증가를 가져오 는데, 본 연구결과를 봤을 때 비육기간이 중간 인 T2구가 포화지방산 비율이 낮아 지방의 경도가 낮을 것으로 판단된다. Virgili 등 (2003)은 도살체중을 높였을 경우 피하지방의 불포화지방산 농도는 낮아졌다고 보고하였는 데, 본 연구결과 재래종과 랜드레이스 교배종 돼지에서는 $200 \sim 220$ 일 비육한 돼지에서 포 화지방산의 비율이 가장 낮은 것으로 나타났 고 이러한 이유는 palmitic acid와 stearic acid 의 감소가 주요한 원인인 것으로 나타났다. 연구결과를 종합해보면 재래종과 랜드레이스 교배종 돼지의 비육기간에 따른 지방산 조성 은 T2구가 $\mathrm{T} 1$ 과 $\mathrm{T} 3$ 구에 비하여 myristic acid, palmitic acid, stearic acid 및 포화지방산의 함 량은 낮았으며, 상대적으로 linoleic acid, arachidonic acid, UFA, EFA, UFA/SFA 및 $\mathrm{EFA} / \mathrm{SFA}$ 비율은 높게 나타났다. 그러나 
Table 7. Changes of fatty acid compositions with feeding periods

\begin{tabular}{|c|c|c|c|}
\hline Treatments $^{1)}$ & $\mathrm{T} 1$ & $\mathrm{~T} 2$ & T3 \\
\hline Myristic acid & $1.13^{\mathrm{a}} \pm 0.09$ & $0.93^{b} \pm 0.09$ & $0.79^{b} \pm 0.10$ \\
\hline Palmitic acid & $20.02^{\mathrm{a}} \pm 0.58$ & $18.54^{\mathrm{b}} \pm 0.54$ & $18.32^{\mathrm{b}} \pm 0.64$ \\
\hline Palmitoleic acid & $2.74 \pm 0.25$ & $2.47 \pm 0.24$ & $2.47 \pm 0.28$ \\
\hline Stearic acid & $14.11^{b} \pm 0.93$ & $11.40^{\mathrm{C}} \pm 0.87$ & $16.28^{\mathrm{a}} \pm 1.03$ \\
\hline Oleic acid & $43.64 \pm 2.09$ & $42.25 \pm 1.97$ & $44.8 \pm 2.32$ \\
\hline Linoleic acid & $12.79^{\mathrm{b}} \pm 1.50$ & $17.21^{\mathrm{a}} \pm 1.41$ & $10.75^{\mathrm{b}} \pm 1.67$ \\
\hline Arachidonic acid & $5.55^{b} \pm 0.95$ & $7.20^{\mathrm{a}} \pm 0.89$ & $6.55^{\mathrm{ab}} \pm 1.06$ \\
\hline $\mathrm{SFA}^{2)}$ & $35.26^{\mathrm{a}} \pm 0.99$ & $30.87^{\mathrm{b}} \pm 0.93$ & $35.40^{\mathrm{a}} \pm 1.10$ \\
\hline $\mathrm{UFA}^{2)}$ & $64.71^{\mathrm{b}} \pm 1.00$ & $69.13^{\mathrm{a}} \pm 0.94$ & $64.60^{\mathrm{b}} \pm 1.10$ \\
\hline $\mathrm{EFA}^{2)}$ & $18.33^{b} \pm 2.23$ & $24.42^{\mathrm{a}} \pm 2.10$ & $17.30^{\mathrm{b}} \pm 2.48$ \\
\hline (UFA/SFA) & $1.89^{\mathrm{b}} \pm 0.09$ & $2.27^{\mathrm{a}} \pm 0.09$ & $1.86^{\mathrm{b}} \pm 0.10$ \\
\hline (EFA/SFA) & $0.52^{\mathrm{b}} \pm 0.08$ & $0.81^{\mathrm{a}} \pm 0.08$ & $0.50^{\mathrm{b}} \pm 0.09$ \\
\hline
\end{tabular}

Means \pm S.D.

a,b,c Means with different superscript in the same row significantly $\operatorname{differ}(\mathrm{P}<0.05)$.

1) T1(below 200days), T2(200 220days), T3(over 220days).

2) SFA(Saturated fatty acid), USFA(Unsaturated fatty acid), EFA(Essential fatty acid).

Palmitoleic acid와 arachidonic acid는 비육기간 에 따른 차이가 없는 것으로 나타났다.

\section{IV 요 약}

재래돼지 수컷과 랜드레이스 암컷을 교배하 여 생산된 돼지 150 두의 비육기간[T1(200일 미만), T2(200 220일), T3(220일 이상)]에 따 른 돼지의 도체특성과 돈육의 이화학적 특성 을 비교한 결과는 다음과 같다. 비육기간이 증가할수록 생체중, 도체중 및 등지방두께는 유의적으로 $(\mathrm{P}<0.05)$ 증가하였다. 또한 최종 도체등급은 비육기간이 증가할수록 유의적으
로 $(\mathrm{P}<0.05)$ 낮았다. 수분 함량과 $\mathrm{pH}$ 는 비육 기간이 증가할수록 유의적으로 $(\mathrm{P}<0.05)$ 낮아 졌으나 조지방 함량은 비육기간에 따른 유의 적인 차이를 보이지 않았다. 육색 및 지방색 은 비육기간이 길어질수록 $\mathrm{L}^{*}$ 값과 $\mathrm{b}^{*}$ 값은 낮아지고, $\mathrm{a}^{*}$ 값은 유의적으로 $(\mathrm{P}<0.05)$ 높아 졌다. 가열 감량은 $\mathrm{T} 1, \mathrm{~T} 3, \mathrm{~T} 2$ 구 순으로 높게 나타났다 $(\mathrm{P}<0.05)$. 전단가는 비육기간이 증가 할수록 낮아지는 결과를 나타내었다. 비육기 간에 따른 지방산 조성의 변화에서 $\mathrm{T} 2$ 구는 $\mathrm{T} 1$ 과 $\mathrm{T} 3$ 에 비하여 myristic acid, palmitic acid, stearic acid 및 SFA는 낮았으며, 상대적으로 linoleic acid, arachidonic acid, UFA, EFA, 
$\mathrm{UFA} / \mathrm{SFA}$ 및 EFA/SFA 비율은 유의적으로 $(\mathrm{P}<$ 0.05) 높았다. 그러나 Palmitoleic acid와 arachidonic acid는 비육기간 간에 따른 함량의 차 이를 보이지 않았다. 본 연구결과를 종합해 보았을 때 재래종과 랜드레이스 교잡종 돼지 는 비육기간이 증가시 생체중과 도체중 및 육색과 연도가 증가하지만 도체등급은 비육 기간의 증가에 의해 낮아지는 것으로 나타났 다.

$$
\mathrm{V} \text { 사 사 }
$$

본 연구는 한국과학재단 지정 진주산업대학교 동물생명산업지역협력연구센터(과제번호 : R122002-053-03003-0)의 연구비 일부 지원에 의한 것으로 이에 감사드립니다.

\section{$\mathrm{VI}$ 인 용 문 헌}

1. Beattiea, V. E., Weatherupa, R. N., Mossb, B. W. and Walkera, N. 1999. The effect of increasing carcass weight of finishing boars and gilts on joint composition and meat quality. Meat Sci. 52: 205-211.

2. Berry, B. W., Smith, G. C., Hillers, J. K. and kroening, G. H. 1970. Effects of sire breed and rearing method on qualitative characteristics of pork. Proceedings of 35th International Congress of Meat Science and Technology. 987-992.

3. Candek-Potokar, M, Zlender, B. and Bonneau, M. 1996. Quality parameters of pig longissimus dorsi muscle as affected by slaughter weight and breed. Proceedings of 42nd International Congress of Meat Science and Technology. 306-307.

4. Candek-Potokar, M, Zlender, B., Lefaucheur, L. and Bonneau, M. 1998. Effects of age and/or weight at slaughter on longissimus dorsi muscle: biochemical traits and sensory quality in pigs. Meat Sci. 48:287-300.

5. Choi, Y. I., Kim, Y. T., Lee, C. L. and Han, I. K. 2000. Carcass and pork quality characteristics by sex and marketing day. J. Anim. Sci. \& Technol.(Kor.) 42(6):933-940.

6. Cisneros, F., Ellis, M., McKeith, F. K., McCaw, J. and Fernando, R. L. 1996. Influence of slaughter weight on growth and carcass characteristics, commercial cutting yields, and meat quality of barrows and gilts from two genotypes. J. Anim. Sci. 74: 925-933.

7. Ellis, M., Webb, A. J., Avery, P., Smithard, R. and Brown, I. 1990. Sex and feeding level effects on the eating quality of fresh pork. Animal Production. 50:551-558.

8. Folch, J., Lees., M. and Sloane-Stanley, G. H. 1957. A simple method for the isolation and purification of total lipids from animal tissues. J.Biol. rnChem. 226: 497-507.

9. Fortin, A. 1980. The effect of slaughter weight on the carcass charicteristics of Yorkshire barrows and gilts. Can. J. Sci. 60:265.

10. Friesen, K. G., Nelssen, J. L., Unruh, J. A., Goodband, R. D. and Tokach, M. D. 1994. Effects of the interrelationship between genotype, sex and dietary lysine on growth performance and carcass composition in finishing pigs fed to either 104 or 127 kilograms. J. Anim. Sci. 72:946-954.

11. Gu, Y., Schinckel, A. P. and Martin, T. G. 1992. Growth, development and carcass composition in five genotypes of swine. J. Anim. Sci. 70:17191792.

12. Krieter, J., Schwerdtfeger, R., Holscher, T. and kalm, E. 1989. Carcass traits, intramuscular fat and meat quality in pigs during the growing period (30 $\mathrm{kg}$ to $120 \mathrm{~kg}$ live weight). 40th Annual Meeting of EAAP, Dublin, Ireland.

13. Martin, A. H., Sather, A. P., Fredeen, H. T. and Jolly, R. W. 1980. Alternative market weights for swine. II. Carcass composition and meat quality. J. of Anim. Sci. 50:699-705.

14. Monin, G., Larzul, C., Roy, P. Le., Culioli, J., Mourot, J., Rousset-Akrim, S., Talmant, A., Touraille, C. and Sellier, P. 1999. Effects of the halothane genotype and slaughter weight on texture of pork. J. Anim. Sci. 77:408-415.

15. Ognjanovic, A., Peric, V. and Josipovic, S. 1973. Carcass composition abd some quality characteristics of muscle tissue as affected by the age and the weight of pigs at slaughter. Proceedings of 19th Meeting of Research Workers. 677-695.

16. Rhim, T. J., Chung K. Y. and Kim, C. J. 1995. Composition and traits of carcass and tenderness of pork from barrows of different chronological ages. Korean J. Food Sci. Ani. Resour. 15(2): 117-121.

17. Sanudo, C., Santolaria, M. P., Maria, G., Osorio, M. and Sierra, I. 1996. Influence of carcass weight 
on instrumental and sensory lamb meat quality in intensive production systems. Meat Sci. 42:195-202.

18. Sather, A. P., Jones, S. D. M., Tong, A. K. W. and Murray, A. C. 1991. Halothane genotype by weight interactions on pig meat quality. Canadian J. of Anim. Sci. 71:645-658.

19. Shuler, R. O., Pate, T. D., Mandigo, R. W. and Lucas, L. E. 1970. Influence of confinement floor structure and slaughter weight on pork carcass characteristics. J. Anim. Sci. 31:31-35.

20. Shuler, R. O., Pate, T. D., Mandigo, R. W. and Lucas, L. E. 1970. Influence of confinement, floor structure and slaughter weight on pork carcass characteristics. J. of Anim. Sci. 31:31-35.

21. Sutton, D. S., Ellis, M., Lan, Y., McKeith, F. K. and Wilson, E. R. 1997. Influence of slaughter weight and stress gene genotype on the water-holding capacity and protein gel characteristics of three porcine muscles. Meat Sci. 46:173-180.

22. Sutton, D. S., Ellis, M., Lan, Y., McKeith, F. K. and Wilson, E. R. 1997. Influence of slaughter weight and stress gene genotype on the water-holding capacity and protein gel characteristics of three porcine muscles. Meat Sci. 46:173-180.
23. Touraille, C., Monin, G. and Legault, C. 1989. Eating quality of meat from European $\times$ Chinese crossbred pigs. Meat Sci. 25:177-186.

24. Touraille, C., Monin, G. and Legault, C. 1989. Eating quality of meat from European $\times$ Chinese crossbred pigs. Meat Sci. 25:177-186.

25. Vergara, H., Molina, A. and Gallego, L. 1999. Influence of sex and slaughter weight on carcass and meat quality in light and medium weight lambs produced in intensive systems. Meat Sci. 52: 221-226.

26. Virgili, R., Degni, M., Schivazappa, C., Faeti, V., Ploetti, E., Marchetto, G., Pacchioli, M. T. and Mordenti, A. 2003. Effects of age at slaughter on carcass traits and meat quality of italian heavy pigs. J. Anim. Sci. 81: 2448-2456.

27. Warkup, C. C., Dilworth, A. W., Kempster, A. J. and Wood, J. D. 1990. $\cdots$ The effects of sire type, company source, feeding regimen and sex on eating quality of pig meat. Animal Production. 50: 550-558.

(접수일자 : 2004. 5. 19. / 채택일자 : 2004. 10. 14.) 